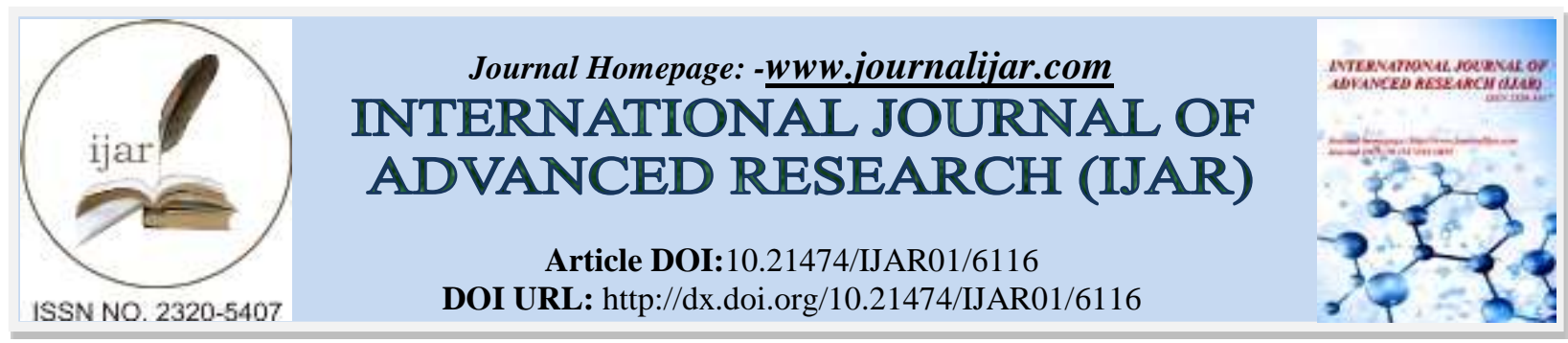

RESEARCH ARTICLE

\title{
RICH SENSORIAL EXPERIENCE OF ARCHITECTURE.
}

\author{
Ar. Madhura Rathod. \\ Associate Professor, Smt.ManoramabaiMundle College of Architecture, L.A.D.Campus, Seminary Hills, Nagpur, \\ Maharashtra, India.
}

\section{Manuscript Info}

Manuscript History

Received: 20 October 2017

Final Accepted: 22 November 2017

Published: December 2017

Keywords:-

Architectural Spaces, Experience,

Perception, Senses.

\section{Abstract}

Experiencing the richness of architecture through senses are the hallmarks of timeless architecture. The interactive process of encoding and decoding forms and spaces in architecture leads to experience. This paper focuses on understanding how the architectural marvel still evokes emotive responses in the perceiver. Exhaustive studies of a large number of architectural marvels obviously have an element of subjectivity with respect to the purpose of study for which the study is conducted. In this paper, our perception of holistic experience on few of the case studies is discussed at length.

Copy Right, IJAR, 2017,. All rights reserved.

\section{Introduction}

Architecture is a form in space which is appreciated visually. It is associated with concepts that are expressed through the perception of its preceptor. Of all the human senses involved in the perception of any architecture, visual sense has hegemony over the others. The perceptions, being subjective, have several channels of expressions which may be contextual, social, cultural, political, religious, climatological, scientific or technological and alike.

Human interaction with any architecture has four basic premises namely sensation, perception, emotion, and experience which are all associated with human senses. The two important issues for perception are architectural form and spaces enclosed in and around this form.

\section{Architecture}

Architecture has been an artifact designed for fulfilling the functional requirement of man. Along with the function, aesthetic, and structural attributes are an integral part of its design. Few attributes are specific and physical in their nature like dimensions, shapes, colors, textures, etc. Architecture involves few intangible elements also which cannot be readily measured like - dynamism in form, architectural language, feelings, and expressions.

\section{Architectural Space}

Architectural Space is experienced as a dynamically inseparable whole which always includes the observer in an essential way. Though space is formless it is found to be the source of all forms. The Upanishad attributes a quality of ether (Akash means sky) to space (Parikh, 2008).

Space is endless, formless, and present everywhere at any time. It is assumed to be beyond evolution and mutation. But, the special quality of architectural space is that it can be experienced as a dynamically inseparable part of every individual as it includes the observer in an essential way. It cannot be manifested but, can be revealed (Parikh, 2008). 
Architectural space should inevitably reflect the intention of the designer and the style of the user. The exterior form and the interior spaces are responsible for reflecting the expression of the building. The architectural elements like walls, roof, and plinths etc. act as a tangible entity that actually integrates the interior spaces with the exterior form. It unites the inner world with the outer, to attribute spatial character.

Activities in architecture should be inter-connected with the help of intermediate building elements and spaces. Holistically, these spaces should act as a sequence of experiences. Though the spaces can be interwoven, they should also have their individual identity. The observer tries to perceive multiple spaces at one instance, which is technically not possible. But, the ability of the observer can help him to think imaginatively. Many times, we assume the further space by standing at a particular location. The momentary sound of the bell reminds us of a temple, the feeling of water trigger nerves in our brain to judge the intensity of temperature. Hence, the perception of architectural spaces changes with the perceiver's position. The interaction between the space and the observer is a continuous process. Different users perceive the same space differently depending upon their preconceived ideas and thoughts. Thus, the role of the designer must be to motivate and integrate the interaction between the space and the observer.

\section{Holistic Experience:-}

The holistic experience begins with the first sight of the structure as seen by the observer. Followed by this, when the observer enters the premise and moves through all the possible spaces of interest, he develops various perceptions using the relevant dominant human senses. This experience is complete when he leaves the premise with a holistic impression about what he has experienced during his visit to a particular site. This paper focuses on describing this process vis-à-vis the role of five senses in what, we conceive as the holistic experience of architecture. The criterion for selection is the factual data on the architecture which qualifies it to be a world-class marvel.

In this study, Indian marvels from two different centuries like-, Sun Temple, Modhera ( $11^{\text {th }}$ Century AD), and The Lotus Temple, Delhi $\left(20^{\text {th }}\right.$ century $\left.\mathrm{AD}\right)$, are selected to get acquainted with the method of experiencing as stated above. What has contributed for the structures to be architectural marvels has been briefly studied by focusing on the following questions:

1. Background for creating the structure,

2. Purpose for which the structure was built,

3. How was the structure built?

4. How the purpose is fulfilled while experiencing the architecture? and

5. Why the structure can be considered as an architectural marvel?

6. The Sun Temple, Modhera, Ahmedabad, Gujarat

Factual Data:-

UNESCO Heritage Site

Built - in-1026-27 AD during the reign of Bhima I of the Chaulukya dynasty.Style: Maru-Gurjara (Chaulukya)

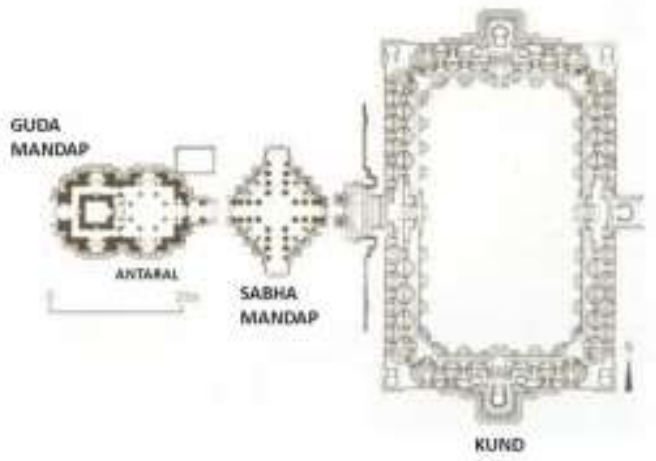

Figure 1:-The plan of the Sun Temple, Modhera, Ahmedabad, Gujarat, India

\section{Background and Purpose:-}

The Sun Temple at Modhera is dedicated to the Sun God. Its ensemble is composed of three parts: the main temple with the Garbhagriha and the mandapa called Gudamandapa, a detached sabhamandapa, and a stepped water tank 
called kund (figure 4.5). All of them share the same east-west oriented axis and face the east, towards the rising sun; to let the first rays of the equinoxes $\left(21^{\text {st }}\right.$ March, and $21^{\text {st }}$ September), the sun strikes the idol in the sanctum (Garbhagriha).

The temple and the pavilion (mandapa) are situated on a raised plinth while the tank is on a lower plane, and connected to the hall along the common axis by a contiguous and ascending flight of steps flanked by a ceremonial archway (torana).

The place welcomes us with a visually appealing tank and the gateway standing gracefully before the backdrop of green trees. Views from across the tank, with a shrine in the foreground, against the backdrop of the steps and the temple, forces to feel the openness of the space. The freshness of the water notices the relationship between the self and the surrounding nature. It brings about the confluence of fire (sun rays) and water for the human body to experience polarization (touch sense) (figure 2).

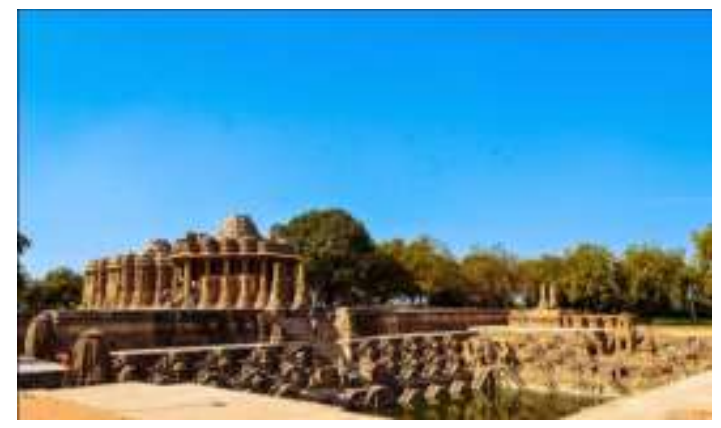

Figure 2:-The Perspective View of the Sun Temple, Modhera, Ahmedabad, Gujarat, India (http://www.inditales.com/architecture-of-sun-temple-modhera)

The perception of the three units simultaneously, the tank as the ablution, the pavilion as the second gathering space and the temple as the abode of the gods are themselves, complete architectural entities. The role of the visual axis, the geometry of the built form, the play of foreground and background, adds to the visual perception that supports the route of movement both visually and physically (figure 3 ).

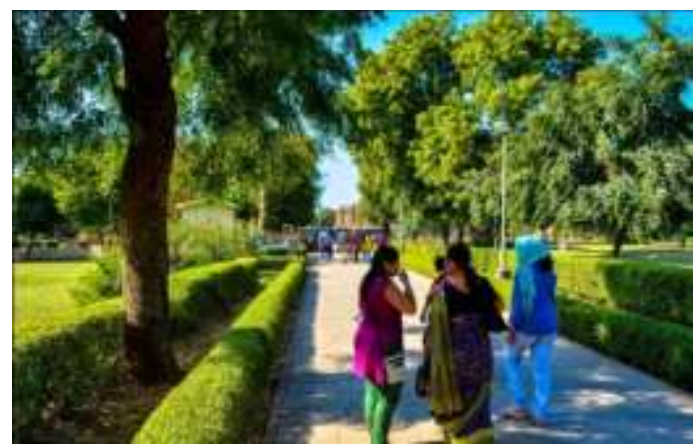

Figure 3:-The Avenue Towards the Temple of the Sun Temple, Modhera, Ahmedabad, Gujarat, India (http://www.inditales.com/architecture-of-sun-temple-modhera)

The visual experience is enhanced because of the animated and episodic unfolding of the intricacies of the ensemble rather than a holistic one-time look of the overall complex. The complex is perceived as a unified composition along a single axis. However, the ritual and circulation route, which determines the movement through the space, guides the experience of the precinct, seen as a sequential overlapping of a series of the visual frame, with the eye being guided upward by the profile of the shikhara (figure 4). 


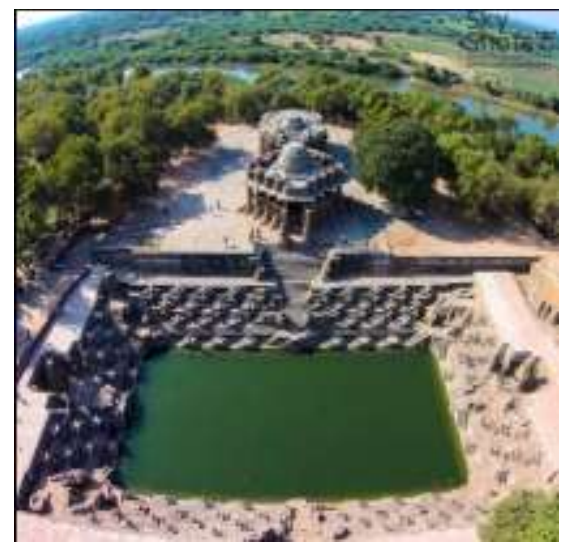

Figure 4:-The Aerial View of the Sun Temple, Modhera, Ahmedabad, Gujarat, India (http://www.inditales.com/architecture-of-sun-temple-modhera)

\section{Experience:-}

As one move towards the temple along the axis, the foreground of the tank begins to register the visual frame. The kinesthetic sense can be experienced while ablution. The sound of the water is the auditory experience and the olfactory sense is triggered by the smell sense. This confluence is a unique experience. however, the absence of water in a tank these days still forces the observer to hypothetically experience the sound of the water, sometimes silent, the other time with the noise of imaginary devotees inside it. One can imagine the beautiful mirror image of the shikhara that must have once been reflected in the tank water. The tank further emphasizes the need to reach the divine after the ablution. The enclosure of the surrounding steps on all sides leaves the only temple in vision. Thus, the tank contributes in bringing about the confluences of visual, auditory, and the kinesthetic senses (figure 5).

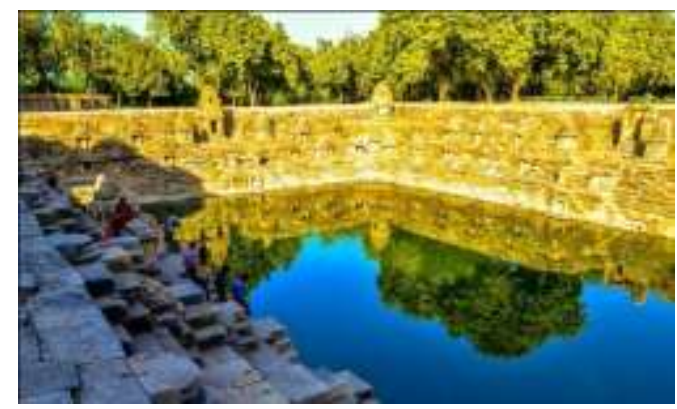

Figure 5: The Kund of the Sun Temple, Modhera, Ahmedabad, Gujarat, India (http://www.inditales.com/architecture-of-sun-temple-modhera)

The plinth is an element which segregates the temple from the tank and enters the pavilion. The panoramic vision of the exterior landscape until arrested by the entry into the hall allows appreciation of its form and proportion of massing. The cool breeze from the surrounding can be felt everywhere in the complex. The hall, though indoors, is well lit due to the opening on all sides. The ranges of vision here are more intimate within a few feet and therefore, the details, elements, and treatment can be appreciated and experienced through senses.

Once within the temple, there are two spaces- the prayer hall (goodhamandapa) and the sanctum (the garbhagriha); both part of the same mass externally but separated internally by a construction of wall planes. These spaces have got a different experience due to its enclosed and dark nature. One can appreciate the play of light and shade here, and therefore of texture. The prayer hall, lit by two windows on either side is perceived as a gathering space, albeit small, due to the central volume and the rising roof of the dome above.

The sanctum, the abode of the deity, is dark and unlit, leaving perception to the imagination and thereby totally integrating the devotee with his conception of God. The senses are stimulated in a sustained rhythm of experiences through mass, form, elements, materials, treatment, light, and shade, texture and finally the inner feeling. 


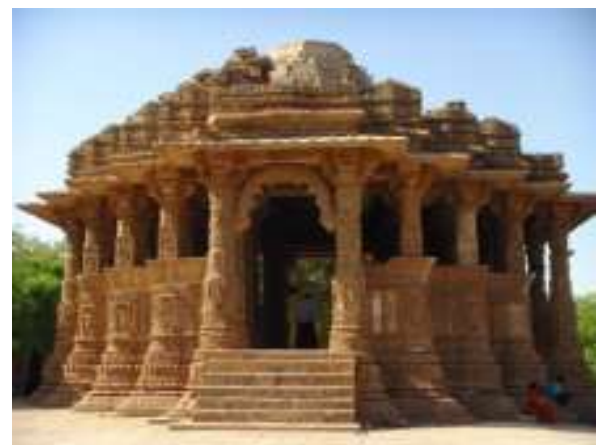

Figure 6:- The Temple of the Sun Temple, Modhera, Ahmedabad, Gujarat, India (http://www.inditales.com/architecture-of-sun-temple-modhera)

This is a beautiful example which serves an architectural palette for the sensorial experience by playing with the usage of the site in terms of placement, orientation and the creation of levels to the proportions of the superstructure. The massing and the kind of entablature, the carvings, and the overlays of symbols are all designed with expert sensitivity and knowledge to have holistic architectural experience (figure 6). This structure till date fulfills its purpose of construction.

The Lotus Temple, New Delhi

\section{Factual Data}

UNESCO Heritage Site

Built by - Architect FariborzSahba in the year 1986

\section{Background}

The Lotus Temple, an architectural marvel has been successful in communicating with the observer through the space sequences, the ambiance generated due to use of water ponds, and the air that is felt due to the green lush gardens around. It is this aspect of architectural parameters that set off an instantaneous dialogue between the user and the architectural product.

\section{Purpose}

It is built by Bahai Authorities and is designed by Architect FariborzSahba to act as a congregational space for people from all communities, religions, and caste. It mainly propagates to meditate for experiencing inner peace by every human being visiting the site.

\section{Experience}

The architectural grace and symmetry of the Lotus Temple just take observer's breadth away. The visual frame of the structure guides the perceiver continuously towards the structure and potentially nourishes him both emotionally and spiritually. The visual dynamics of moving through the space and sensory perception of it is vital to wholesome architecture (figure 7).

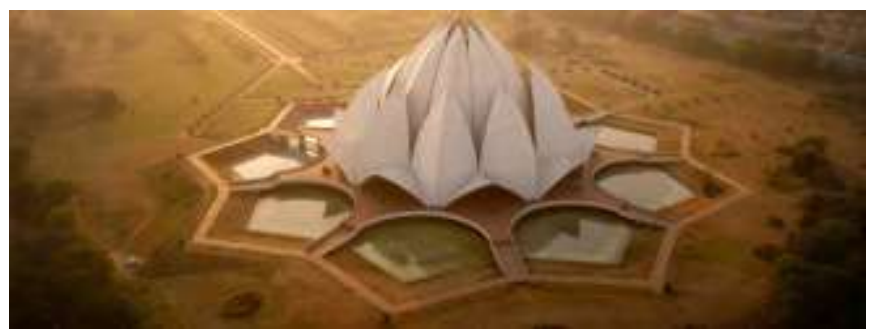

Figure 7:-Ariel view of the Lotus Temple, New Delhi, India (http://www.google.co.in/lotus+temple\&source

The entry to the temple is through a gate that leads to a pathway with landscaped gardens on both sides. The perceiver has to take off his shoes and deposit them in the shoe keeping centre. The touch sense becomes dominant as soon as the naked feet step on the floor. The dynamic perception of form, the space through movement and the changing points of view is the most outstanding experience of this architectural marvel. Spaces here in the complex 
are perceived and conceived through movement. The journey, the process of moving through the transitional space activates visual, auditory and kinesthetic sense prominently.

The lotus temple reaches a height of more than 40 meters. One starts seeing the 27 giant white patels of marble in a lotus shape, springing from nine pools and the walkways indicative of the nine unifying spiritual paths of the Bahai faith. The temple complex consists of the centre, the library, the administration building and the rest room block.

The clues from movement, inherent to space, are revealed sequentially. The time gap required for the deconditioning of the previous and the pre-conditioning of the next is taken care of while designing spaces sequentially. This gradual unfolding of spaces creates a sense of curiosity within the visitors and involves them in the process to experience through human senses. The walkways with beautiful curved balustrades, bridges, and stairs, surround the nine pools representing the floating leaves of the lotus. Apart from serving an aesthetic function, the pools also help to have the pleasing and soothing experience of the breeze (figure 8).

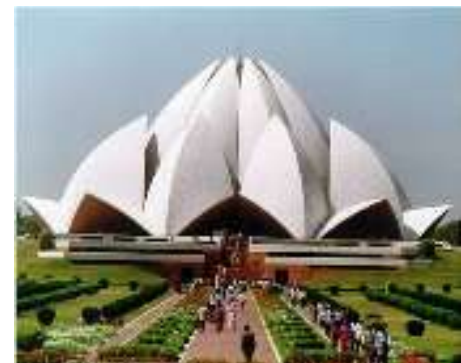

Figure 8: The Avenue Towards the Structure of the Lotus Temple, New Delhi, India (http://www.google.co.in/lotus+temple\&source)

One reaches the entrance, the nine massive arches giving the sense of permeability and legibility. The row of steps through each arch leads into the main hall. The nine doors of the lotus temple open onto a central hall, capable of holding up to 2500 people. Total calmness is experienced in the hall. This auditory perception of the indoor space is the subtle transition of an individual from the universal state of consciousness to the state of inner self. The extreme silence, where the sound level is below 20 decibels, human being starts responding to the physical realm of the space. This qualitative experience is unconscious but they cannot be hidden. The overall form as well as interior spaces, act as mirrors reflecting the inner experience. The nature of an enclosed inner space in the Lotus Temple is very much determined by what demarcates it from the exterior. The element - concrete petals which are meeting place of the exterior and the interior forces, express the inherent duality of this spatial expression. The lotus, as seen from outside, has three sets of leaves or petals, all of which are made out of thin concrete shells. The outermost set of nine petals, called the 'entrance leaves', open outwards and form the nine entrances all around the outer annular hall. The next set of nine petals called the 'outer leaves', point inwards. The entrance and the outer leaves together cover the outer hall. The third set of nine petals, called the 'inner leaves', appear to be partly closed. Only the tips open out, somewhat like a partly opened bud. This portion, which rises above the rest, forms the main structure housing the central hall. Near the top where the leaves separate out, nine radial beams provide the necessary lateral support. Since the Lotus is open at the top, a glass and steel roof at the level of the radial beams provides protection from rain and facilities the entry of the natural light into the auditorium. All these structural aspects add to the visual

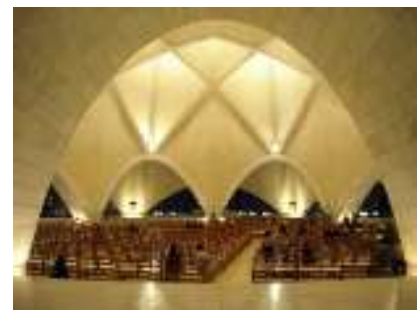

Figure 9: The Interior View of the Lotus Temple, New Delhi, India (http://www.google.co.in/lotus+temple\&source) 


\section{Findings:-}

On completing these studies, the following facts were prominently noted:

1. Any built environment is a source which transmits the signals that are experienced by human senses.

2. The passage of signals is through organs like eyes, ears, nose, skin, and mouth.

3. Receiving signals and their decoding completes the process of experience.

4. All though the mechanism of this remains same, the outcome, in the form of experience, considerably changes depending upon the typology under consideration.

5. While experiencing architecture, though all senses are involved, at a moment only one or two senses are predominant over the other.

6. The hierarchy of the prominent sense varies for different typologies.

7. The visual experience of architecture is always in relation to its context.

8. Architectural experiences changes with the perceiver's position in space.

9. Viewers become an active participant in the spatial experience of the form and spaces if the structure has the inherent quality of triggering the human senses.

10. The dialogue between the perceiver and space is stimulated by architectural elements.

11. Interpretation of the character of the space can differ for every individual according to their own perception, to create more of a personalized and internalized experience.

The inferences of these studies stated above clearly establish a strong linkage between the human perception through senses and the holistic experience of architecture. However, it can also be seen from the details of the examples discussed that this link gets established in most of the cases without a conscious effort, on the part of the designer to maximize the role of each perception in experiencing an architecture as a whole.

\section{References:-}

1. Blesser, B. and Salter, L-R. (2007). Spaces speak, are you listening? experiencing aural architecture. Cambridge, Mass.: MIT Press.

2. Bachelard, Gaston, The Poetics of Space, New York: Orion Press,1964.

3. Bloomer, K. \&. (1997). Body, Memory, and Architecture. New Haven: Yale University Press.

4. Corbusier, L. (1960). Towards a New Architecture. New York: Praeger Publishers Inc.

5. Classen C., Howes D, Synnot, A., 1994, Aroma- the cultural history of smell; London; Routledge

6. Carterette (Editor), Edward Friedman, Morton P., 1978, Handbook of perception- volume VI-A-Tasting and smelling; New York; Academic Press.

7. Deshpande, S. A. (2013). Design Dialog: Dialectics of Design in Architecture. New Delhi: Council of Architecture.

8. Dickson, John D., The Mastery of Space, The University of Auckland School of Architecture,1982.

9. Droog, S. \&. (2009). Emotion in Architecture. n.d.

10. Dodds, G. T. (2002). 1. Dodds, G., Tavernor, R., \& RykweBody and building: Essays on the changing relation of body and architecture. Cambridge, MA: MIT Press.

11. Dongre, A.R. (2010). Aesthetics of Built form- A Search in Visual and Structural Dynamism. VNIT, Nagpur

12. Engen T., 1982, The Perception of Odors; New York; Academic Press

13. Fox, M., \& Kemp, M. (2009). Interactive Architecture. New York: Princeton Architectural Press.

14. Flint, A. R. The Structural Design and Construction of Two Baha'i Houses of Worship. The Structural Engineer Journal of Baha'i Studies,no.65.

15. Franck, K. A. (2007). 3. Franck, K. A., Lepori, R. B.Architecture from the inside out: From the body, the senses, the site, and the community. Chichester: Wiley-Academy.

16. Freeman, M. (2005). Meditative spaces. New York: Universe Publishing.

17. http://www.dictionary.com/browse/sound. (n.d.).

18. http://www.bahaistudies.ca/journal/files /jbs/7.3.Sahba(scanned).pdf.

19. Kokel, H. \&. (2012). The Image of the City: The Study of User's Perception of a Street in Indian Context (RITH-1095).

20. Lawson, B. (2003). How Designers Think. Oxford, UK: Architectural Press.

21. Lawson, B. (2005). The Language of Space. Oxford,UK: Architectural Press.

22. Lefebvre, H. (1998). The Production of Space. Oxford,UK: Blackwell Publishers Ltd.

23. Merleau-Ponty, M., C. Smith, et al. (2002). Phenomenology of perception. London; New York: Routledge. (Original work published 1945).

24. Meiss, P. v. (1990). Elements of architecture: from form to place. London: Van Nostrand Reinhold. 
25. Merleau-Ponty M., 1999, Phenomenology of Perception; London; Routledge

26. Morris,David, The Sense of Space, United States: State University of New York Press, 2004

27. Morris, D. (2004). The sense of space. Albany: State University of New York Press.

28. Malnar, J. M. (2004). Sensory design. Minneapolis: University of Minnesota Press.

29. Merleau-Ponty, M. (n.d.). Phenomenology of perception. n.d.

30. Pollio, V.,1960, Vitruvius: The Ten Books on Architecture. New York: Dover Publications.

31. Parikh, P.(2008). Hindu Notion of Space-Making. Ahmedabad.SID Publication Cell.

32. Pallasmaa, J. (2005). The eyes of the skin: architecture and the senses. Chichester, Hoboken, NJ: WileyAcademy; John Wiley \& Sons.

33. Pallasmaa, J. \&. (2005). Encounters: Architectural essays. n.d.: Architectural essays.

34. Pallasmaa, J. (1994). The Architecture of the seven senses. London: Academy Editions.

35. Pallasmaa, J. (2011). The Embodied Image: Imagination and Imagery in Architecture. Chichester: John Wiley \& Sons.

36. Rasmussen, S. E. (1959). Experiencing Architecture. Cambridge, MA: M.I.T. Press.

37. Bentley, Alcock, Murrain, Mcglynn, Smith. (1985). Responsive Environment. Cornwall: Butterworth Heinemann Ltd.

38. Stalder, F. (Director) (2001, January 9). The Space of Flows: notes on emergence, characteristics and possible impact on physical space. 5th International PlaNet Congress. Lecture conducted from Paris 